症例

青酸化合物服用により食道狭窄を来した 1 例について

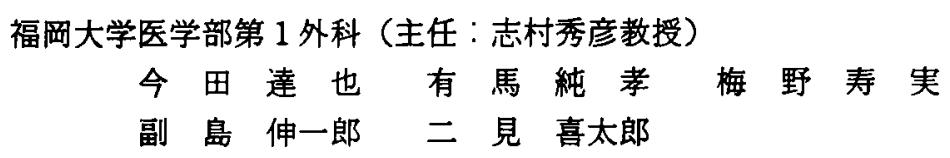

\title{
A CASE OF ESOPHAGEAL STRICTURES BY CYANID
}

Tatsuya IMADA, Sumitaka ARIMA, Toshimi UMENO

Shinichiro SOEJIMA, and Kitaro FUTAMI

First Department of Surgery (Director : Prof. H. Shimura) School of Medicine

Fukuoka University Fukuoka, Japan

良性食道㹨窄はその原因として酸あるいはアルカリを誤领または自殺目的で拎用後に おこる腐蝕性食道狭窄，機械的損傷後の洀痕性食道狭窄，逆流性食道炎などがある。

今回，われわれは，青酸化合物を自殺目的で服用し食道狭窄を来した 1 例を経験した ので報告すると共に本邦の良性食道狭窄症の症例報告を集計し文献的考察を加えた.

症例は36歳, 男. 主訴は睘下障害. 現病歴として昭和56年11月 5 日, 青酸化合物を自 殺目的として服用し，解毒剂（チ才硫酸ナトリウム）にて一命は取り留めたが，中权神 経障害が現われた。食道レ線検査で気管分吱部より2 3cm 肛門側より噴門部まで約 10 $\mathrm{cm}$ の高度狭窄が認められた。食道鏡では，EDチューブがぎりぎり通る程度の高度狭窄 が認められた。手術は栄養改善と共に非開胸下食道拔去術により食道要全摘術，胃管に よる食道再建術を施行した，術後経過は良好である。

实引用語：度䖝性食道炎，食道换窄，青酸化合物

I.はじめに

良性食道狭窄はその原因として酸あるいはフルカリ を誤领または自殺目的で领用後におこる腐蝕性食道狭 窄, 譏械的損倁後の渡痕性食道狭窄, 逆流性食道炎な どがある。特に酸あるいはフルカリの服用により発生 する属触性食道狭窄例が多く，しかも激烈なすのが多 いわれわれは青酸化合物を自殺目的で服用し食道狭 窄を来した 1 例を経験したので報告する。

$$
\text { II. 症例 }
$$

患者：36歳，男性.

主訴：蟭下困難 現病歴：昭和56年11月 5 日，青酸 化合物を服用。量，䈨度等は不明，某病院に運ばれる b意識不明, 呼吸停止, 瞳孔散大, 血圧測定不能の状 態であった。解毒剂(千オ硫酸ナトリウム2 2 フンプル) 觧注し一命は取り留めたが約 1 週間後の意識回復と共 に㗪下困難, 構音障害, 軽度の錐体路障害も加わり酸 秦欠乏による中枢神経障害が疑われた。昭和 56 年 12 月
23日，上肢，下影の不随意運動が加わり12月29日以後 経口摄取不能となり昭和57年 1 月 11 日当科入院となっ た.

入院時現症：栄盖不良以外特に異常なし. 神経学検 查では, 錐体路, 錐体外路（淡荅球）の障害あり舌, 下額の振せん, 構音障害, 腱反射六進, 病的反射 $(+)$, 前傾姿勢であった。食道透視では，気管分岐部より2 3 $\mathrm{cm}$ 肛門側より噴門部まで約 $10 \mathrm{~cm}$ の高度の狭害，狭窄 部より口側の食道拡張が認められた（図 1 ).

食道鏡では，門歯より $29 \mathrm{~cm}$ に狭鿽が認められ $\mathrm{ED}$ チューブがぎりぎり通る程度のむのであり，口側に口 イコブラキーが認められたが，潰場、ビラン等は認め られなかった（図2）.

手術：昭和57年 5 月27日, 栄養改善と共に非開胸下 食道抜去術により食道严全摘術，胃管による食道再建 術を施行した。切険標本：食道下部は著しい㹨窄と共 に，不規則な地図様の潰瘍性病変を示していた。胃粘 


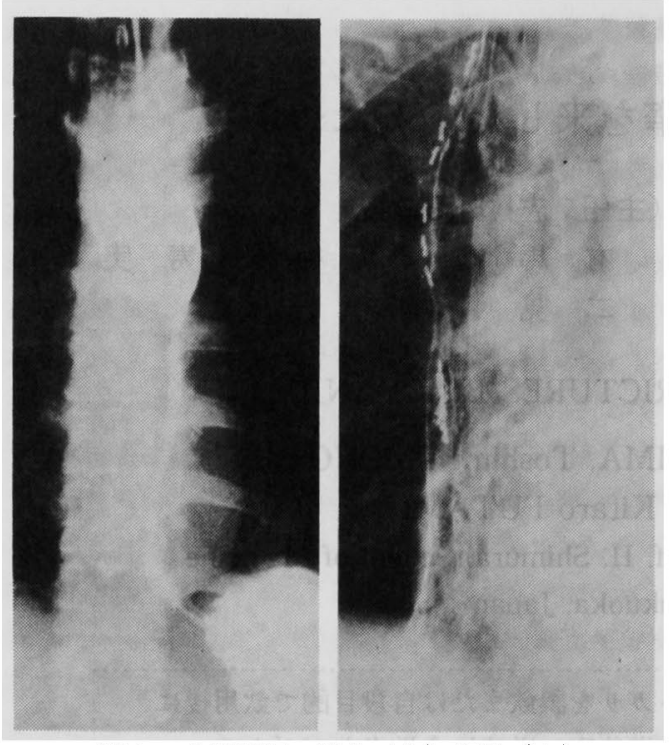

图 1 食道透視，術前（左）術啳（右）

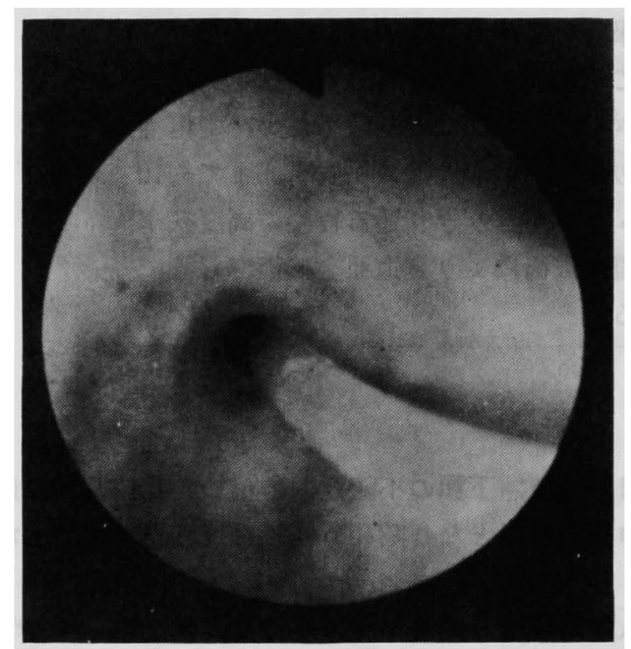

図2 会道鏡：EDチューブがぎりぎり通る程度の狭 窄である.

膜にも散在性に浅い、潰瘍性病変が認められた（图 3）。

組織学的所見：下部食道に演偒 (UI II) を形成し, 表面は苔状物で被れ，粘膜下層には中等度のリンバ球， 形質細胞の浸潤と強い線維化がみられる（図4）。

\section{III. 考 察}

本邦1225) 35) に拈いて報告された良性食道㹟窄症166 症例を検討すると表 1 のごとく腐蝕性食道狭窄が圧倒 的多数を占め, 腐蝕原因は, 塩酸と苛性ンーダが主で やや塩酸が多かった。アルカリでは苛性カリ、アンモ ニアなどがみられた。他薬片による副作用, 熱㲻, 機

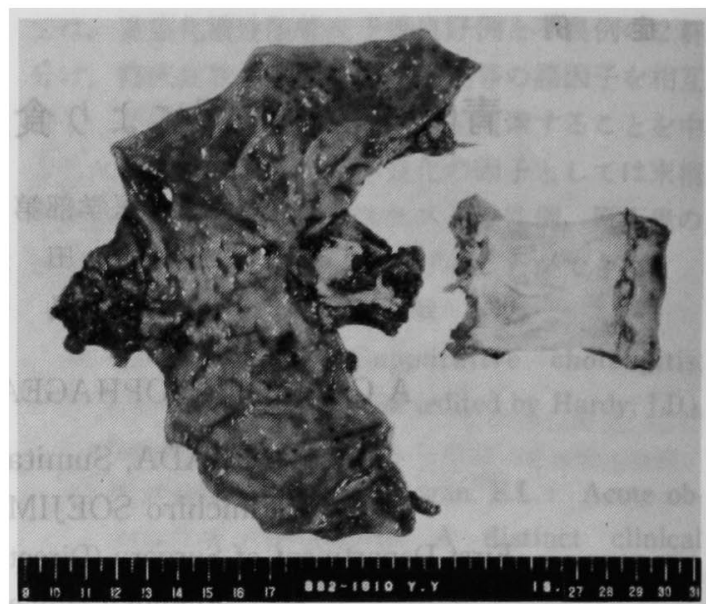

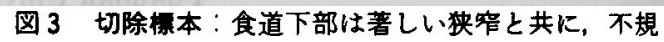
則な地図様溃煬が認められ，胃粘膜にす浅い散在性 の溃楊が認められる。

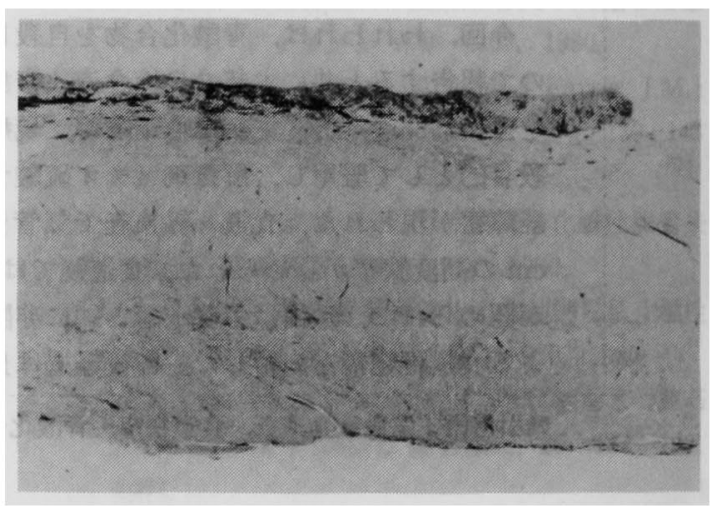

图4 組識所見：下部食道溃場（U1 II）を形成し，表 面は苔状物で被れ，粘膜下層には，中等度のリンハ 球, 形質細胞の浸潤と線維化がみっられる。

械的食道㹟窄む数例みられた，発生機序は腐触剂の種 類, 瀑度, 量および作用時間により異っていた。 われ われの症例のよ5な青酸化合物による食道狭窄例は， 知る限りでは本邦には報告されていなかった．青酸化 合物の致死量は $0.2 \mathrm{~g}$ であり多量になると救命の余地

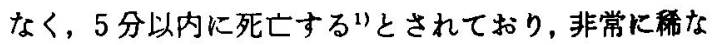
症例であった，本症例は青酸化合物という以外，その 正確な青酸化合物名, 量については不明であったが， いつれにしてもてルカリ性であるため食道狭窄を来た したものと思われた，幸いに一命を取り留めたが一般 的には，中枢神経系への障害が現九最初に皮質か，炏 に基底核，視床下部，中脳の順に下行性に侵される ${ }^{239}$ と言われておりっこの症例です㷋荅球が侵されていた。 
良性食道狭窄における本邦報告例の性別に関しては， 表1のごとく男女比は $6 ： 5$ ではとんど差がなく，使 用薬郕については表 2 のことくであった，自殺目的の

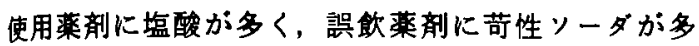

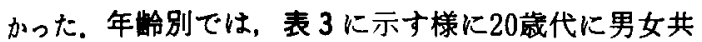
にビークがあり，自殺の多い年代と一致していた，次 に発症より手術までの期間とその間の対処の仕方は, 6 力月以内が䄪 $40 \%$, 半数以上が 1 年以内に手術を受 け，表 4 のごとく胃度造設後手術例かi $34.5 \%$ と一番多 く、ブシー又は胃瘦造設，あるいは両者併用後の根治 手術は64\%であった。 ゆえにプジーのみで根治手術を 施行しなかった症例は少なくこれのみによる狭窄食道 の払張はあまり期待できず，比較的軽度のるのに有効 であるが，定期的に使用しないと有効でないと思われ

表 1 良性企道张鹤应本邦166症例

（1957年～1981年）

\begin{tabular}{l|c|c|c|c}
\hline & 男 & 女 & 不 明 & 計 \\
\hline 地 酸 & 24 & 28 & 12 & 64 \\
\hline カセインータ & 28 & 16 & 8 & 52 \\
\hline 酸 & 1 & 4 & 0 & 5 \\
\hline カセイカリ & 3 & 2 & 0 & 5 \\
\hline サク 酸 & 1 & 1 & 1 & 3 \\
\hline フンモ=ア & 1 & 1 & 0 & 2 \\
\hline その他のフルカリ & 3 & 2 & 3 & 8 \\
\hline その他の酸 & 2 & 0 & 1 & 3 \\
\hline その 他 & 10 & 10 & 4 & 24 \\
\hline 計 & 73 & 64 & 29 & 166 \\
\hline
\end{tabular}

表 2 使用苝剧（1957年～1981年）

\begin{tabular}{|c|c|c|c|c|}
\hline & 自 殺 & 譟 领 & 不 明 & 計 \\
\hline 塩 & 39 & 8 & 17 & 64 \\
\hline カセインータ & 10 & 22 & 20 & 52 \\
\hline 硫酸 & 2 & 2 & 1 & 5 \\
\hline カセイカリ & 1 & 3 & 1 & 5 \\
\hline サク酸 & 0 & 3 & 0 & 3 \\
\hline フンモニ & 1 & 0 & 1 & 2 \\
\hline その他のフルカリ & 1 & 7 & 0 & 8 \\
\hline その他の酸 & 0 & 3 & 0 & 3 \\
\hline その他（㮐剂） & 1 & 5 & 8 & 14 \\
\hline 計 & 55 & 53 & 48 & 156 \\
\hline
\end{tabular}

裹 3 自耤者の年龄別

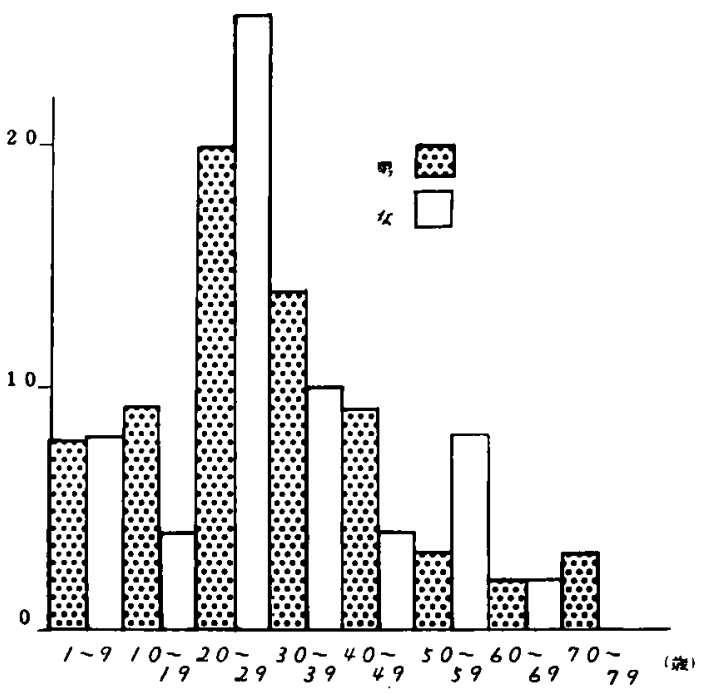

表 4 手術の有無と手術までの対処の仕方 (1957年－1981年)

\begin{tabular}{|c|c|c|c|}
\hline & 手術(一) & 手術( +) & 計 \\
\hline (1) プーシー & 8 & 13 & 21 \\
\hline （2）胃ろ5造設 & 2 & 38 & 40 \\
\hline$(1)+(2)$ & 9 & 19 & 28 \\
\hline $\begin{array}{l}\{(1)+(2) \text { 又は } \\
(1),(2)\}+ \text { ステロイト }\end{array}$ & 15 & 6 & 21 \\
\hline 計 & 34 & 76 & 110 \\
\hline
\end{tabular}

た.またステロイド併用が行われておりむしろステロ イド併用例には根治手術を施行しない例の方が多かっ た、ステロイドを食道狭窄に使用することは，1950年 にSpainの報告以来45)，有効な治療法として使用さ れ，受傷後のショックのみならす瘦痕形成の予防とし て有奻とされてきた，根治手術に関しては，結腸食道 再建術が主で非開胸下結腸移植が35.6\%を占め，中で む賛否両論あるが，順ぜん動性が約 $80 \%$ であった。こ の様に結腸を用いる場合，高位の狭窄例に対しても充 分長い遊離結腸片が得られ移植腸管の作製が困難でな ( ${ }^{61}$ ため数多くの施設で施行されている。また，胃が腐 蝕剂により障害されている例が多く胃を利用できない のも大きな原因となっていると思われた，本症例は胃 の障害が少なく胃管を用いることができた，良性食道 狭害に対してブジーによる拡張術は110例中21例に施 行されていたが，そのうち手術を要したのは13例 (62\%)となっておりブジーによる効果はあまり期待で 
きないよらに思われる，资症が筋㬝以上に及んでいる あのについてはその効果が少なく”, 手術的に処置す べと思われるが，粘膜下層程度までの比較的浅いも のに関してはブジーによる効果も期待できるすのと思 われた。

\section{IV. 結 語}

青酸化合物を自殺目的で服用したアルカリによる食 道狭窄の稀な症例を提示すると共に本邦の良性食道狭 窄例について愉討し文献的考察を加光た。

本論文の要旨は第15回胸部外科学会九州地方会に括いて 発表した。

文 献

1）南 貞男：急性ンアン化合物中毒 (青酸中毒)，外 科治療, $36: 605,1977$.

2）南 貞男: 青酸化合物中毒. 数急医学, 第 3 巻 10 号, $1227,1979$.

3) Pasquale F. Finelli : Changes in the base ganglia following cyanide poisoning. J. Comput. Assist. Tomoyr., Vol. 5, No. 5, 1981.

4) Spain, D.M., et al.: The effect of cortison on the formation of granulation tissure in mice. Am. J. Path., 26 : 710-718, 1973.

5）井上鉄三他：腐触性食道炎已二次性食道狭窄，耳 㗋, 45巻 1 号, 17-22, 1973.

6）阿保七三郎他：塩酸第下による屚触性食道㹟害に 対与る胸腔内結腸移植の 1 治験例，外科，24巻10 号, 104-106, 1962.

7）高場利博：腐触性食道狭窄の外科的治療経跧，日 臨外医会誌，第34回 2 号 46-49，1973.

8）林 亘男：腐㟴性食道狭害の外科的治療の検討, 日気食会報，29(5)：39-317４4-322，1978.

9）河合清隆：機能性食道㹟窄症の 1 例，耳喉， 47 巻8 号, 545-548， 1975.

10）中山恒明：胃大弯部形成に上る代用食道につい て，日気食会報，12巻，113-5１19-11，1961.

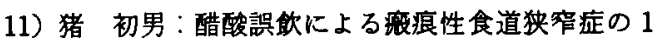
例，日気食会報，12(3)：138-142，1961.

12）小野 变：=ーランデル試菜に原因与る腐螌性底 痕性食道㹟管症の一治騟例，日気食会報，11巻， $166-170, S 35,5$.

13）里村紀作：食道张窄症，外科治療，42(5)： $538-546,1980,5$.

14）高場利博：属触性食道㹨窄の外科的治療経験, 日 臨外医会誌，34(2)：150-153， 1973.

15）柿坂光彦：Fundic patch 法を応用した腐触性食
道狭窄の 1 例，日胸外，27(5)：783，1979，5。

16）烟野良待：SLE，薬物過敏症に上ると思われた良 性食道㹨悎に対する外科治瘵の問題点，日胸外， $27(5): 784,1979,5$.

17）吉田幸男：食道㹨窄とその治療，日胸外，27(5)： $784-785,1979,5$.

18）別所 隆：良性会道㹟窄に対する手術例の榙討， 日胸外，27(5):785，1979，5.

19）中山亘明：腐蝕性食道㹟窄に対す万自家晹管遊崔 移植術一特に手術式について，日臨外，25(1)： $48-49,1964$.

20）葛西洋一：腐蜆性食道决窄に対する食道再健の经 臨, 日臨外，16(4)：248，1968.

21）谷口 遥：厇籁な旅痕性食道狭窄に対する食道再 建征として完全遊離腸管移植成功例について，手 訹, 17(3):262-266, 1963，3.

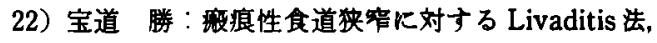
手訹，33(9)：1071-1073，1979，10.

23）井上鉄二：腐䖝性食道资と二次性食道㹟窄，耳喉， 45(1): 13-18，1973，1.

24）大井能司：腐触性食道狭窄症，小児外科 14 巻3， $321-327,1982,3$.

25）川崎勝弘：広筑囲腐触性食道㹟窄症に対する食道 ハイバス造設，外科治療，36(1)：128-133，1977， 1.

26）鍋谷欣市：瘦痕性食道张窄，外科，40(1)： 1148-1153，1978，10.

27）青山興司：食道狭窄症に対する新ブジーの考案， 日小外, 13(7)：1147-1151，1977，12.

28）秋山洋：結腸使用に上る腐触性食道狭窄の手 訹, 日本胸部臨床，33(9)：609-615，1974，9.

29）桂 重次：食道㹟窄, 臨床消化器病学, 4(3): 183-190, 1955.

30）中山恒明：瘄痕性食道㹨窄に対する手術につい て。外科, $14(6): 295-301,1952$.

31）中村嘉三：腐鳋性食道㹟窄症，日気食会報， $17(5): 214-221,1966$.

32）松野正宏：数室にお战食道良性㹨窄，日胸外， 25(4): 427, 1977, 4.

33）別所隆：良性食道㹟窄の模討，日胸外，25(4)： $428,1977,4$.

34）佐野文男：激痕性食道狭窄の手術之予後，日胸外， 25(4):428, 1977, 4.

35）夏田康則：非観血性䅡部食道㹟窄，日胸外， 25(4) : 428, 1977, 4. 